\title{
Effect of temperature and photon fluence rate on gametophytes and young sporophytes of Laminaria ochroleuca Pylaie
}

Received: 2 April 2001 / Received in revised form: 31 August 2001 / Accepted: 17 September 2001 / Published online: 1 November 2001 (C) Springer-Verlag and AWI 2001

\begin{abstract}
We analysed the effects of temperature and photon fluence rate on meiospore germination, growth and fertility of gametophytes, and growth of young sporophytes of Laminaria ochroleuca. Maximum percentages of germination (91-98\%) were obtained at $15^{\circ} \mathrm{C}$ and $18^{\circ} \mathrm{C}$, independent of photon fluence rate. Optimal development of female gametophyte and maximum fecundity and reproductive success of gametophytes occurred at $15^{\circ} \mathrm{C}$ and $18^{\circ} \mathrm{C}$ and at 20 and $40 \mu \mathrm{mol} \mathrm{m}{ }^{-2} \mathrm{~s}^{-1}$. Maximum relative growth rate of young sporophytes after 2 weeks of culture was achieved under the same conditions. L. ochroleuca gametophytes cannot reproduce and growth of its sporophytes is not competitive at temperatures close to $10^{\circ} \mathrm{C}$.
\end{abstract}

Keywords Laminaria Gametophyte Sporophyte · Cultures $\cdot$ Seaweed

\section{Introduction}

Light and temperature are the primary abiotic factors responsible for the vertical zonation and geographical distribution of seaweeds (van den Hoek 1982a; Lüning 1990). For this reason, light quantity and quality and temperature responses of the biological cycle of seaweeds have been the subject of considerable attention.

These aspects have been investigated in the order Laminariales and, in some cases, results have deepened our knowledge of its biogeography and phylogeny (tom Dieck 1993). There is evidence for there having been a recent radiation of this order, which most probably evolved in the North Pacific (Lüning 1990), including species in both hemispheres, from the Arctic to warm

Communicated by K. Lüning

J.L. Izquierdo · I.M. Pérez-Ruzafa (

Departamento de Biología Vegetal I, Facultad de Biología,

Universidad Complutense, 28040 Madrid, Spain

e-mail: iperuz@bio.ucm.es

Tel.: +34-91-3945055, Fax: +34-91-3945034 temperate waters. However, most species belonging to the section Digitatae of the genus Laminaria are restricted to the Atlantic Ocean. Laminaria ochroleuca is an interesting species because it has an unusual distribution compared with the general distribution of the genus Laminaria. It is considered to be the only warm-temperate species of the digitate members of the genus in the northern hemisphere (tom Dieck 1992). Its range extends to the north of Africa (Gayral 1957) and the Mediterranean Sea (Giaccone 1969), and is the only species of the genus, other than Laminaria rodriguezii, that lives in this temperate sea. Further to the north, L. ochroleuca reaches the south of the British Isles (Norton 1985). It is most abundant in the north-west of the Iberian Peninsula. There are some studies of temperature tolerance and survival in darkness of L. ochroleuca gametophytes (tom Dieck 1993), fertility of female gametophytes and temperature tolerance of sporophytes (tom Dieck 1992). However, the lowest survival temperature demonstrated experimentally in L. ochroleuca is not consistent with the temperature tolerance corresponding to the distribution limit of this species. Furthermore, no studies have been carried out to establish the light requirements of the young sporophytes of $L$. ochroleuca and their interaction with temperature.

The study reported in this paper aimed to obtain new information about the effect of temperature and photon fluence rate and their consequences for the biological cycle of $L$. ochroleuca. We analyse their effects on meiospore germination, growth and fertility of gametophytes, and growth of young sporophytes, and relate the observed responses to the habitat and geographical distribution of this species.

\section{Materials and methods}

\section{Gametophyte culture}

Light and temperature requirements of spores vary with environmental conditions (Lee and Brinkhuis 1988; Lee 1992). For this reason, fertile sporophytes of $L$. ochroleuca were collected between August and October in 1995 and 1996. Samples were harvested 
from La Coruña $\left(43^{\circ} 22^{\prime} \mathrm{N} 8^{\circ} 26^{\prime} \mathrm{W}\right.$, NW Spain) at a depth of 5-6 m in the sublittoral zone by scuba diving. Reproductive activity of L. ochroleuca sporophytes is at a maximum during these months. The sorus pieces, which were obtained from five individuals, were rinsed with filtered sea water, wiped and stored overnight at $10^{\circ} \mathrm{C}$. Zoospores were released by immersing the sorus pieces in Provasoli's enriched seawater (PES; Starr and Zeikus 1987). Iodine supplement was added following the method of Tatewaki (1966). A mixture of meiospore suspensions from the five individuals was inoculated in $50 \mathrm{~mm}$ diameter Petri dishes with $20 \mathrm{ml}$ PES. Three or four coverslips $(18 \times 18 \mathrm{~mm})$ were placed at the bottom of each Petri dish. Meiospores were spread on each coverslip at a density of 24-32 spores $\mathrm{mm}^{-2}$. During the first week of culture, a $\mathrm{GeO}_{2}$ solution was added ( $1 \mathrm{ml}$ of aqueous saturated solution of $\mathrm{GeO}_{2}$ $1^{-1}$ PES) in order to eliminate diatoms (Lüning and Neushul 1978). The culture medium was changed every week. A Sylvania 20w/ $20 \mathrm{CW}$ fluorescent lamp was used as a white light source. A photoperiod of $12 \mathrm{~h}$ light/12 h dark was employed. Two Petri dishes, each containing four coverslips with gametophytes, were cultured at all combinations of four different temperatures $(10,12,15$ and $\left.18^{\circ} \mathrm{C} \pm 0.5^{\circ} \mathrm{C}\right)$ and four different photon fluence rates $(5,10,20$ and $40 \mu \mathrm{mol}$ photons $\mathrm{m}^{-2} \mathrm{~s}^{-1}$ ). Photon fluence rates were measured using a Li-Cor LI 1000 photometer with an LI 190sz sensor.

Gametophytes were maintained in culture for 1 month. One coverslip was harvested every 5 or 7 days. Percentage germination was determined on the basis of germ-tube production by counting 500 meiospores at random in five groups of 100 , for each combination of temperature and photon fluence rate between the first and fifth day. Percentage of female gametophytes was calculated counting 500 gametophytes from five groups of 100, for each combination of conditions. Fecundity $(F)$ and reproductive success (RS) of gametophytes were calculated for each condition after Lee and Brinkhuis (1986):

$F=(a+b) /(a+b+c)$

$\mathrm{RS}=a /(a+b+c)$

where $a$ is the number of female gametophytes with sporophytes, $b$ is the number of female gametophytes with oogonia and $c$ is the number of female gametophytes without oogonia. These parameter values were estimated from more than 250 female gametophytes, from five groups of 50 gametophytes. These in vivo observations were made with a Nikon Labophot AFX-DX optical microscope with a Nikon WI 20/0.4 immersion objective and CFWN $15 \times / 14$ eyepieces.

Vegetative growth of gametophytes was determined by measuring the maximum diameter of the primary cells of 20 female gametophytes for each combination of culture conditions, 10 days after the establishment of cultures. Growth was measured using a Microm image analyser. The increase in diameter of the primary cell of the female gametophyte is a reliable character for the estimation of vegetative growth (Lüning and Neushul 1978; Lüning 1980). To calculate this, gametophytes were fixed on the coverslips in $4 \%$ formalin for $2 \mathrm{~h}$, briefly washed in distilled water, and then fixed in glycerogelatine solution $(7 \mathrm{~g}$ gelatine, $50 \mathrm{ml}$ glycerine, $42 \mathrm{ml}$ distilled water and $1 \mathrm{~g}$ phenol). This procedure resulted in shrinkage of 10\% compared with live cells (Lüning 1980).

\section{Culture of young sporophytes}

Two months after cultures were established at 12 and $15^{\circ} \mathrm{C}$ and at 20 and $40 \mu \mathrm{mol} \mathrm{m}-2 \mathrm{~s}^{-1}$, young sporophytes measured between 0.6 and $2 \mathrm{~mm}$ in length. They were removed and transferred to aerated 1-1 beakers with PES. In these aerated beakers, sporophytes were cultivated at different temperatures $\left(10,12,15\right.$ and $\left.18^{\circ} \mathrm{C} \pm 0.5^{\circ} \mathrm{C}\right)$, different photon fluence rates for each temperature $(5,10,20$ and $40 \mu \mathrm{mol} \mathrm{m} \mathrm{m}^{-2} \mathrm{~s}^{-1}$ ) with $12 \mathrm{~h}$ light per day. The medium was changed every week. Sporophyte surface area was measured using a Microm image analyser. Two weeks after the transfer, relative growth rate was calculated for five individuals following Han and Kain (1996):

$R=\left(\ln A_{2}-\ln A_{1}\right) / t_{2}-t_{1}$

where $A_{1}$ and $A_{2}$ are the areas at times $t_{1}$ and $t_{2}$ in days, respectively.

\section{A}

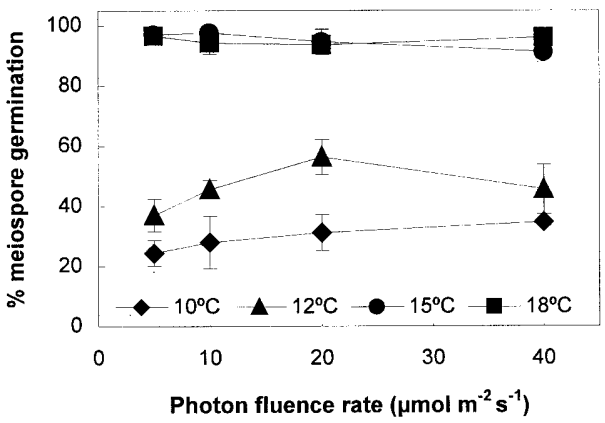

B

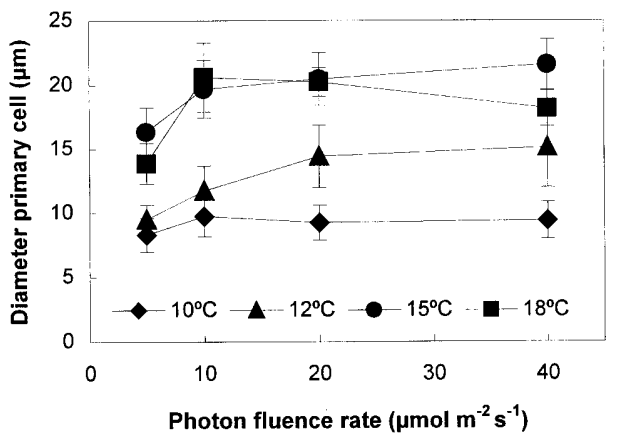

C

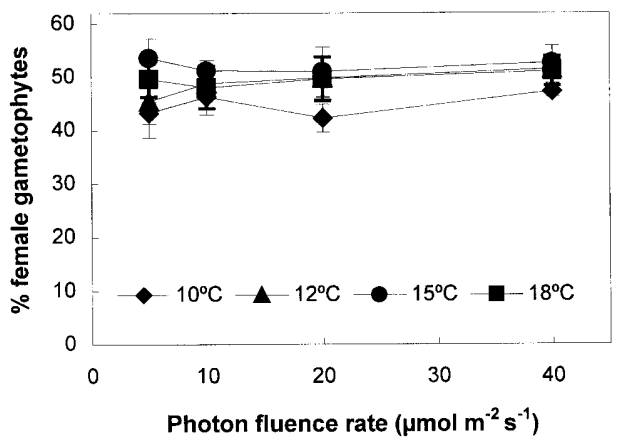

Fig. 1 A Percentage germination of meiospores considered on the basis of germ tube production 5 days after meiospore inoculation, B mean maximum diameter of female gametophyte primary cell 10 days after meiospore inoculation and $\mathbf{C}$ percentage of female gametophytes at different photon fluence rates in Laminaria ochroleuca cultivated at four different temperatures. Bars represent standard errors

\section{Data analysis}

Values of meiospore germination, maximum primary cell diameter, sex ratio and relative growth rate of young sporophytes obtained under different conditions of temperature and photon fluence rate were compared by two-way analysis of variance (ANOVA). Significance was concluded for values of $P<0.05$. To reduce heterogeneity among variances, variables expressed in percentages (meiospore germination and sex ratio) were arcsinetransformed, and the maximum diameter of primary cells was logtransformed. Variance homogeneity was checked using Bartlet's test. Differences, when obtained, were analysed by the StudentNewman Keuls (SNK) test. All analyses were carried out following standard procedures described in Sokal and Rohlf (1995). 
Fig. 2 Different types of morphological development of Laminaria ochroleuca gametophytes under different experimental culture conditions. A development at $15,18^{\circ} \mathrm{C}$ with $20,40 \mu \mathrm{mol} \mathrm{m}{ }^{-2} \mathrm{~s}^{-1}$, B development at $12^{\circ} \mathrm{C}$ with 10,20 and $40 \mu \mathrm{mol} \mathrm{m} \mathrm{m}^{-2} \mathrm{~s}^{-1}$, and at $15,18^{\circ} \mathrm{C}$ with $10 \mu \mathrm{mol}$ $\mathrm{m}^{-2} \mathrm{~s}^{-1}, \mathbf{C}$ development at $10^{\circ} \mathrm{C}$ and at 12,15 and $18^{\circ} \mathrm{C}$ with $5 \mu \mathrm{mol} \mathrm{m} \mathrm{m}^{-2} \mathrm{~s}^{-1}$ (occasionally fertile). Arrows indicate antheridia; $f$ fecundation; $s$ sporophyte. Bar $26 \mu \mathrm{m}$

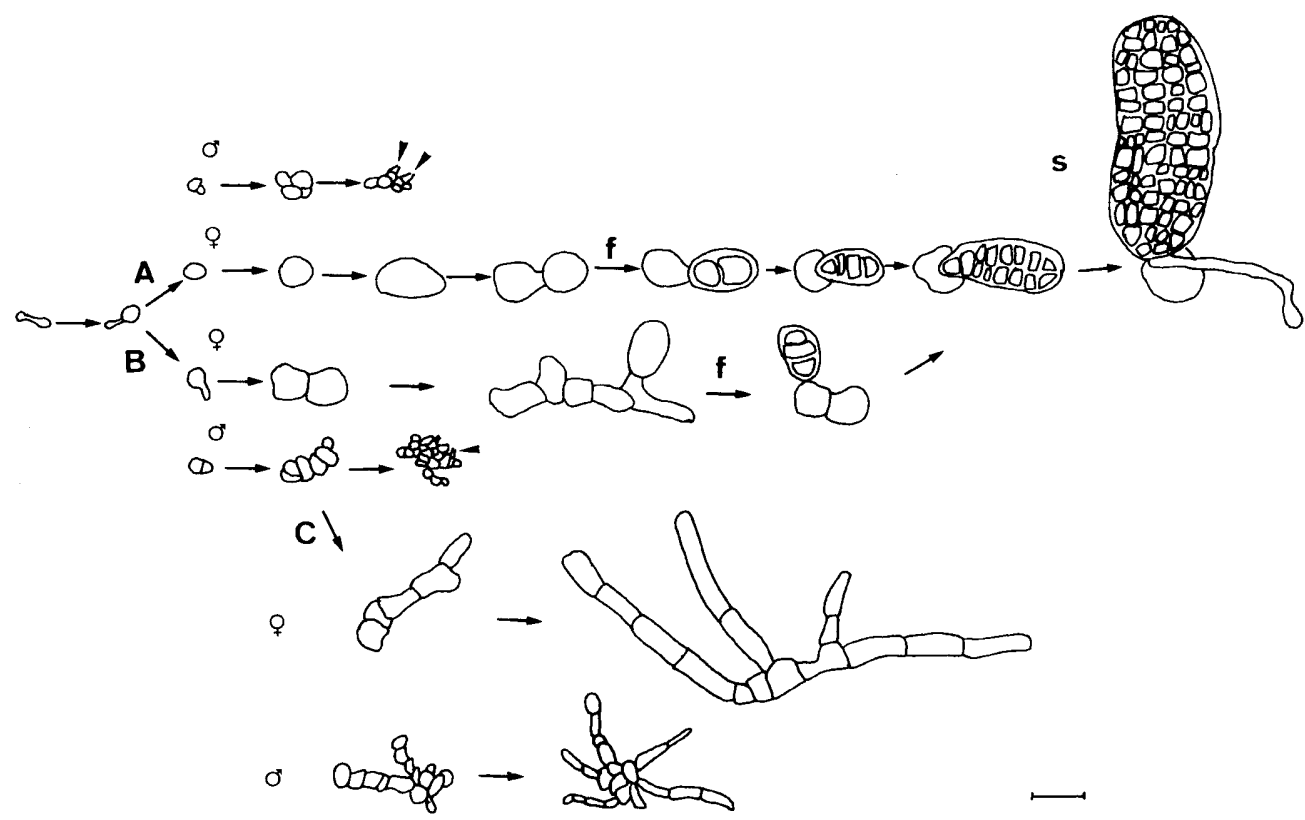

\section{Results}

Germination of meiospores

Meiospores of L. ochroleuca measured $5.55 \mu \mathrm{m}( \pm 0.30 \mu \mathrm{m}$; $n=50)$ in diameter. All meiospores were attached between 12 and $24 \mathrm{~h}$ after their liberation. Meiospores then formed the germination tube. Percentage germination was $10 \%$ by $24 \mathrm{~h}$ following the release of zoospores and between $17 \%$ and $61 \%$ by the third day, reaching a maximum on the fifth day. Fig. 1A shows the percentage meiospore germination after 5 days, related to photon fluence rate at four different culture temperatures. Meiospores cultivated at $10^{\circ} \mathrm{C}$ had low (24-35\%) germination percentages. Maximum germination percentages (91-98\%) were obtained at $15^{\circ} \mathrm{C}$ and $18^{\circ} \mathrm{C}$, and were similar at the four different photon fluence rates studied. Results of a two-way ANOVA (Table 1) showed that photon fluence rate only significantly influenced meiospore germination of $L$. ochroleuca at $12^{\circ} \mathrm{C}$, and not at the other temperatures.

\section{Vegetative growth of gametophytes}

Ten days after liberation of meiospores, primary cells of the gametophytes were formed under all experimental conditions. Figure 1B shows the variation of the maximum diameter of primary cells of female gametophytes in relation to photon fluence rate at the four culture temperatures. This trait was light-saturated at photon fluence rates of about $20 \mu \mathrm{mol} \mathrm{m} \mathrm{m}^{-2} \mathrm{~s}^{-1}$ at all temperatures. Maximum values of this variable were produced at $15^{\circ} \mathrm{C}$ and $20,40 \mu \mathrm{mol} \mathrm{m} \mathrm{m}^{-2} \mathrm{~s}^{-1}$; and also at $18^{\circ} \mathrm{C}$ and $10,20 \mu \mathrm{mol}$ $\mathrm{m}^{-2} \mathrm{~s}^{-1}$. Two-way ANOVA (Table 1) showed temperature, photon fluence rate and the interaction between them to influence the size of primary cells of $L$. ochroleuca gametophytes significantly.
Table 1 Two-way ANOVA of meiospore germination, maximum diameter of primary cell, sex ratio of the gametophytes and relative growth rate of sporophytes of Laminaria ochroleuca cultivated at four temperatures $\left(10,12,15\right.$ and $\left.18^{\circ} \mathrm{C}\right)$ and four photon fluence rates (PFR: 5, 10, 20 and $40 \mu \mathrm{mol} \mathrm{m}^{-2} \mathrm{~s}^{-1}$ ). Groups were compared using the Student-Newman Keuls (SNK) test

\begin{tabular}{|c|c|c|c|c|}
\hline Variable & $d f$ & MS & $F$ ratio & $P$ \\
\hline \multicolumn{5}{|c|}{$\%$ meiospore germination } \\
\hline $\begin{array}{l}\text { Temperature } \\
\text { PFR } \\
\text { Temperature } \times \text { PFR } \\
\text { SNK test: } 15=18>12\end{array}$ & $\begin{array}{l}3 \\
3 \\
9\end{array}$ & $\begin{array}{r}14065.95 \\
15.96 \\
64.37\end{array}$ & $\begin{array}{r}980.03 \\
1.11 \\
4.48\end{array}$ & $\begin{array}{l}<0.001 \\
0.35 \\
0.001\end{array}$ \\
\hline \multicolumn{5}{|l|}{ Primary cell diameter } \\
\hline $\begin{array}{l}\text { Temperature } \\
\text { PFR } \\
\text { Temperature } \times \text { PFR }\end{array}$ & $\begin{array}{l}3 \\
3 \\
9\end{array}$ & $\begin{array}{l}1.86 \\
0.28 \\
0.03\end{array}$ & $\begin{array}{r}560.10 \\
85.19 \\
8.89\end{array}$ & $\begin{array}{l}<0.001 \\
<0.001 \\
<0.001\end{array}$ \\
\hline \multicolumn{5}{|c|}{ SNK test: $15>18>12>10 ; 40=20>10>5$} \\
\hline \multicolumn{5}{|c|}{$\%$ female gametophytes } \\
\hline $\begin{array}{l}\text { Temperature } \\
\text { PFR } \\
\text { Temperature } \times \text { PFR } \\
\text { SNK test: } 15>18=12\end{array}$ & $\begin{array}{l}3 \\
3 \\
9\end{array}$ & $\begin{array}{r}53.72 \\
8.90 \\
4.95\end{array}$ & $\begin{array}{r}13.06 \\
2.16 \\
1.20\end{array}$ & $\begin{array}{c}<0.001 \\
0.10 \\
0.31\end{array}$ \\
\hline \multicolumn{5}{|c|}{ Relative growth rate of sporophytes } \\
\hline $\begin{array}{l}\text { Temperature } \\
\text { PFR } \\
\text { Temperature } \times \text { PFR }\end{array}$ & $\begin{array}{l}3 \\
3 \\
9\end{array}$ & $\begin{array}{l}0.03 \\
0.06 \\
0.01\end{array}$ & $\begin{array}{r}56.40 \\
107.77 \\
14.58\end{array}$ & $\begin{array}{l}<0.001 \\
<0.001 \\
<0.001\end{array}$ \\
\hline SNK test: $18=15>12$ & . & $10>5$ & & \\
\hline
\end{tabular}

Vegetative growth of female gametophytes was based on the volume increase of primary cells, while vegetative growth of male gametophytes was based on multiple division of cells. In L. ochroleuca gametophytes, we observed three different patterns of vegetative development (Fig. 2). In the first, the female gametophytes stayed with its primary cell or with an additional cell 
$10^{\circ} \mathrm{C} 5 \mu \mathrm{mol} \mathrm{m} \mathrm{s}^{-1}$
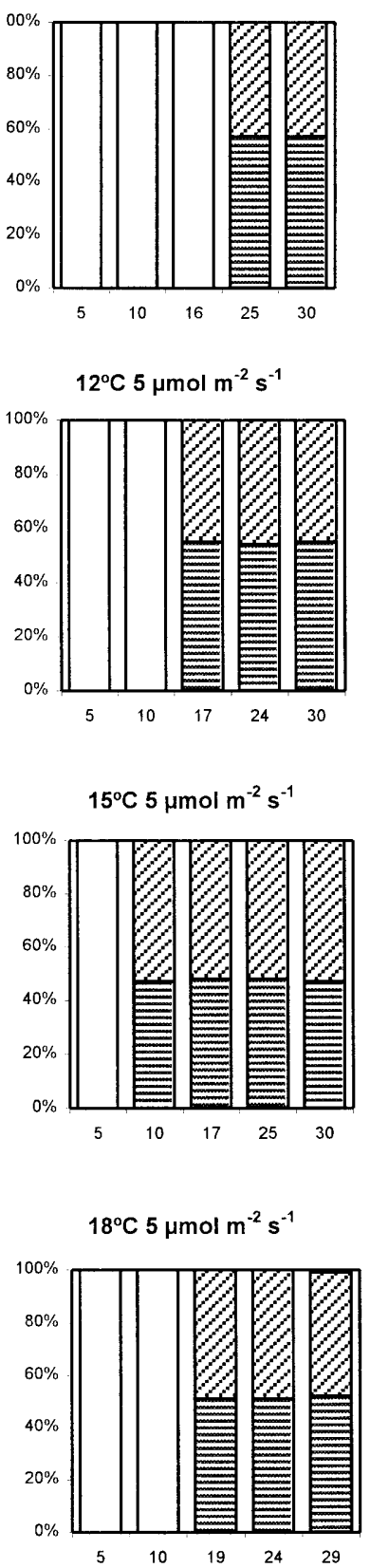
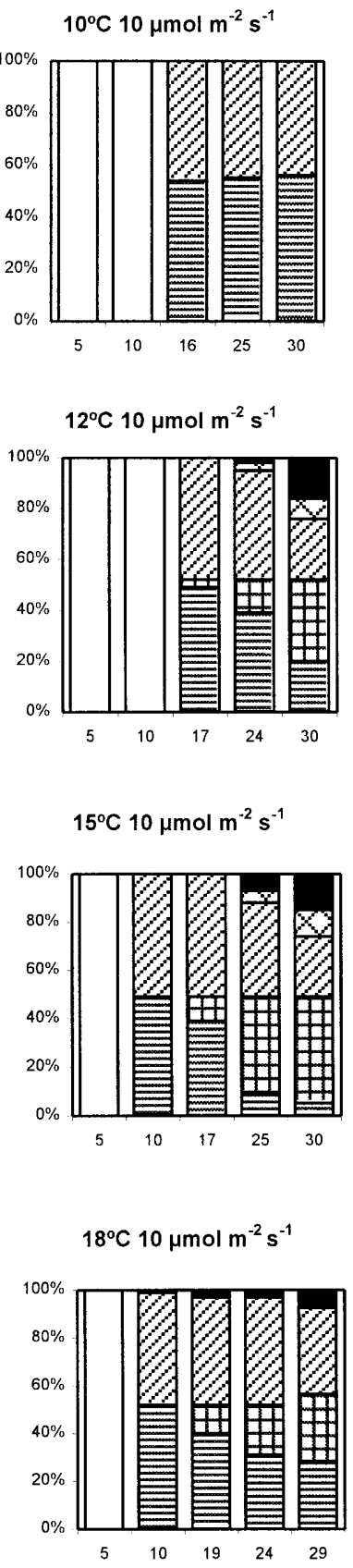
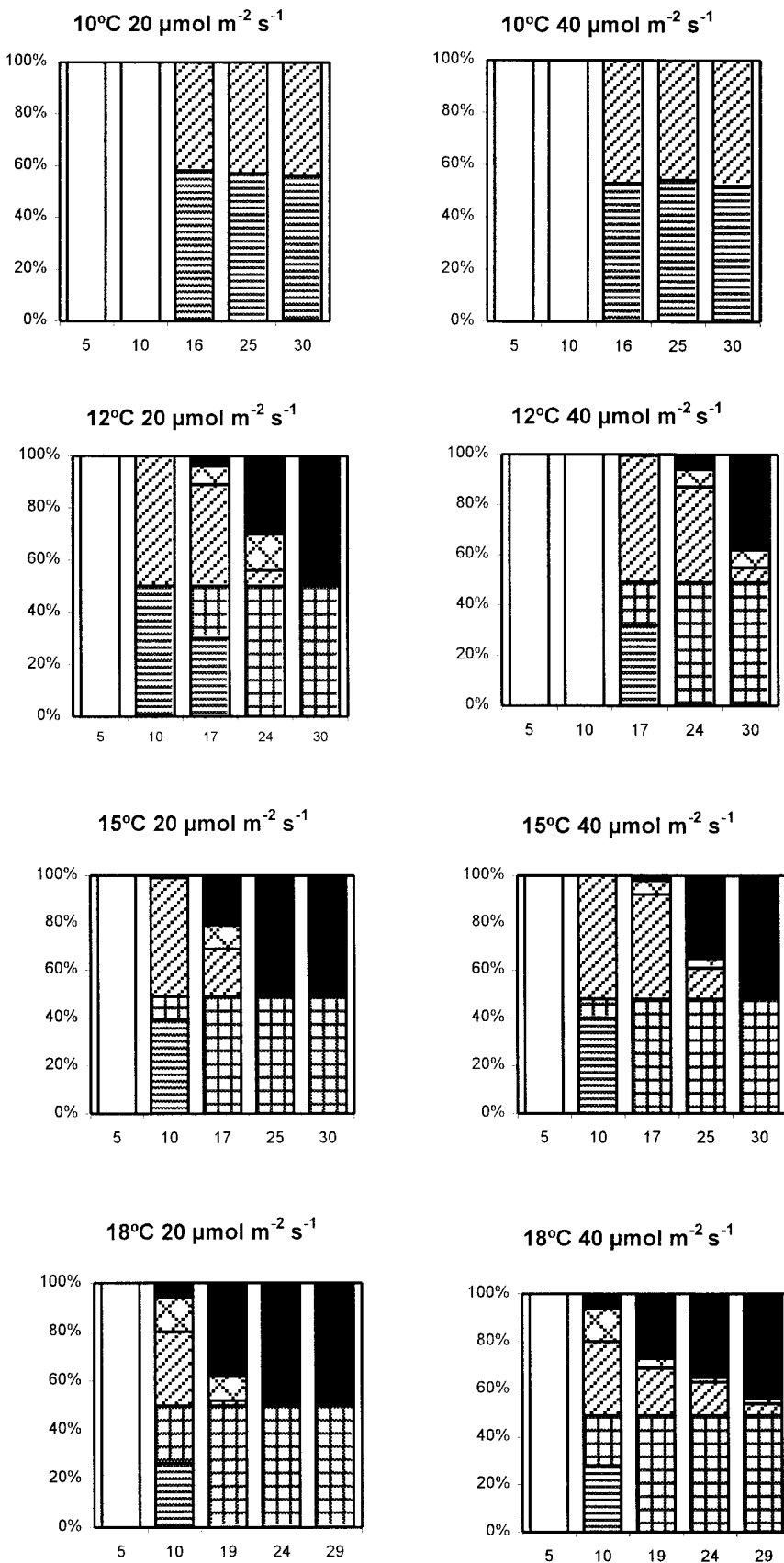

\section{Time (days)}

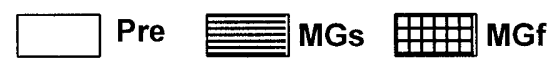

Fig. 3 Different stages attained by Laminaria ochroleuca gametophytes under different light and temperature culture conditions. Pre Presexuals, $M G s$ sterile male gametophytes, $M G f$ fertile male gametophytes, FGs sterile female gametophytes, FGf fertile female gametophytes, $S$ sporophytes
(1-2 cells), and the male gametophytes stayed with a few cells in the form of a compacted filamentous ball. This appearance was observed at $15^{\circ} \mathrm{C}$ and from 10 to $40 \mu \mathrm{mol} \mathrm{m}{ }^{-2} \mathrm{~s}^{-1}$, and at $18^{\circ} \mathrm{C}$ and $20-40 \mu \mathrm{mol} \mathrm{m}^{-2} \mathrm{~s}^{-1}$. In the second pattern, the gametophytes had more cells (3-10 in female gametophytes) and had a greater surface area than those adopting the former pattern. We observed this in gametophytes cultivated at $12^{\circ} \mathrm{C}$ and $20-40 \mu \mathrm{mol}$ $\mathrm{m}^{-2} \mathrm{~s}^{-1}$, at $18^{\circ} \mathrm{C}$ and $10 \mu \mathrm{mol} \mathrm{m} \mathrm{m}^{-2} \mathrm{~s}^{-1}$, and also at all tem- 
Fig. 4 Fecundity (A) and reproductive success $(\mathbf{B})$ of female gametophytes of Laminaria ochroleuca achieved during experimental cultures, at different conditions of photon fluence rate and temperature. Results at $10^{\circ} \mathrm{C}$ are not included because fecundity and reproductive success was null. Bars indicate standard errors
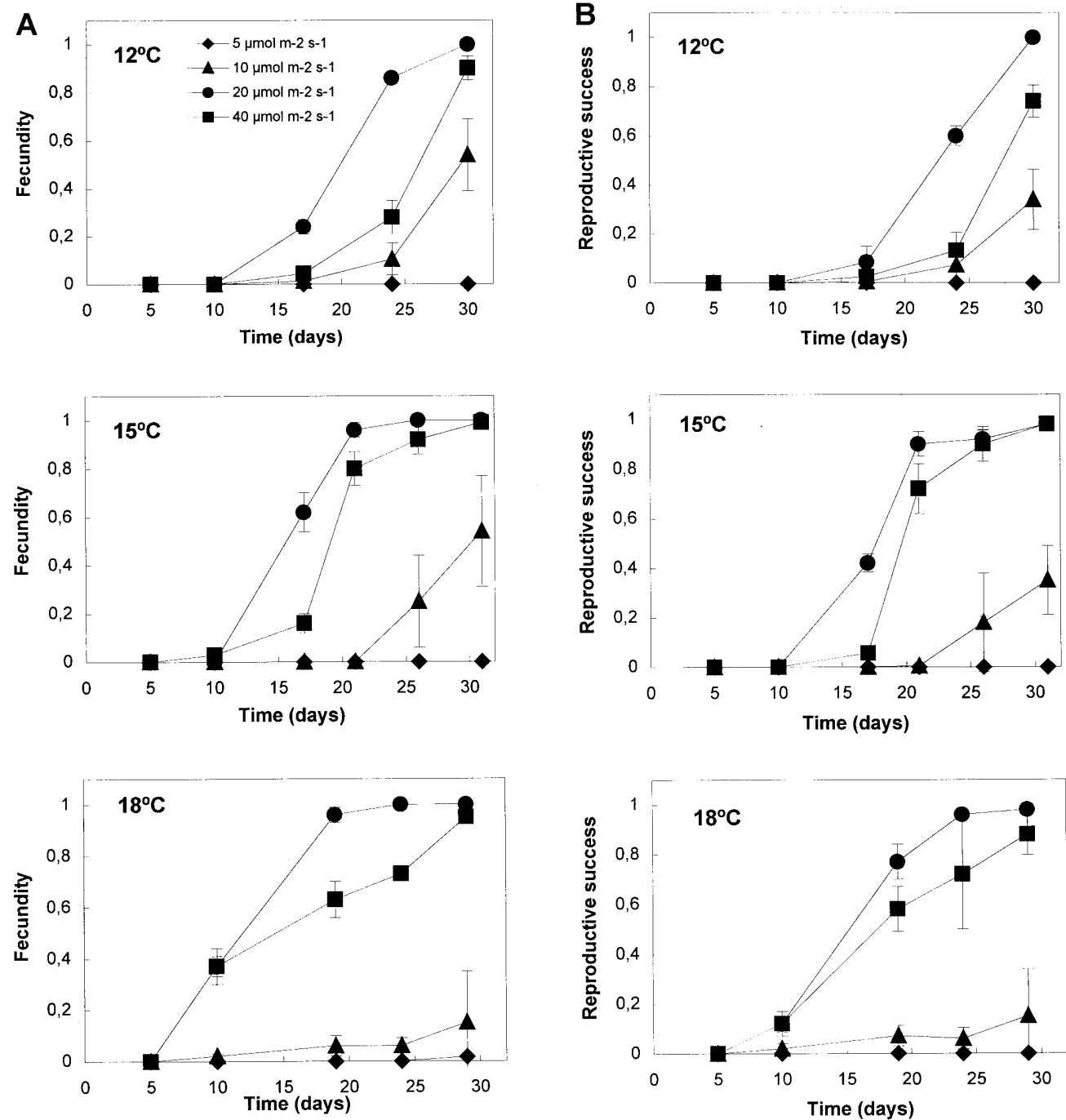

peratures at the lowest experimental photon fluence rate, $5 \mu \mathrm{mol} \mathrm{m} \mathrm{m}^{-2} \mathrm{~s}^{-1}$. Finally, with the third pattern, gametophytes had the largest surface areas and comprised more than 20 cells. They attained a length exceeding $250 \mu \mathrm{m}$. This pattern arose at $10^{\circ} \mathrm{C}$ and $10-40 \mu \mathrm{mol} \mathrm{m}^{-2} \mathrm{~s}^{-1}$, and at $12^{\circ} \mathrm{C}$ and $10 \mu \mathrm{mol} \mathrm{m}{ }^{-2} \mathrm{~s}^{-1}$.

\section{Reproduction}

Figure 1C shows the percentage of female gametophytes under all experimental conditions by day 10. Results suggested nearly equal proportions of the two sexes in each case $\left(\chi_{1}^{2}<\chi_{0.05[1]}^{2} n=500\right.$, for each condition). However, a two-way ANOVA (Table 1) revealed that temperature significantly influenced the sex of the gametophytes. However, photon fluence rate did not influence sex expression, and there was no significant interaction between the two factors. The maximum observed percentages of female gametophytes were obtained at $15^{\circ} \mathrm{C}$ (51-54\%); minimum percentages $(42-47 \%)$, were observed at $10^{\circ} \mathrm{C}$.
The development of gametocysts varied with the different physical conditions to which they were exposed (Fig. 3). At $10^{\circ} \mathrm{C}$, neither antheridia nor oogonia formed during the experiment. In gametophytes cultivated at 12 , 15 and $18^{\circ} \mathrm{C}$, gametocysts developed during the second week of culture, at all photon fluence rates except at $5 \mu \mathrm{mol} \mathrm{m} \mathrm{m}^{-2} \mathrm{~s}^{-1}$. Gametophytes cultivated at this photon fluence rate only developed gametocysts at $18^{\circ} \mathrm{C}$, and even then, this was after 25 days of culture and in a very low percentage (1.6\% of female gametophytes with oogonia).

The relationship between fecundity and culture period is shown in Fig. 4A. At 12,15 and $18^{\circ} \mathrm{C}$, maximum values were obtained at a photon fluence rate of $20 \mu \mathrm{mol} \mathrm{m} \mathrm{m}^{-2} \mathrm{~s}^{-1}(F=1)$. At 15 and $18^{\circ} \mathrm{C}$, these values were attained 5 days before the end of experiment. Similar results were obtained at these temperatures and $40 \mu \mathrm{mol} \mathrm{m}^{-2} \mathrm{~s}^{-1}\left(F=0.99 \pm 0.01\right.$ at $15^{\circ} \mathrm{C}, F=0.95 \pm 0.02$ at $18^{\circ} \mathrm{C}$, and $F=0.90 \pm 0.05$ at $12^{\circ} \mathrm{C}$ ), although more time was required to achieve these results. With a photon fluence rate of $10 \mu \mathrm{mol} \mathrm{m} \mathrm{m}^{-2} \mathrm{~s}^{-1}$, fecundity was lower $(F=0.15-0.54)$. 


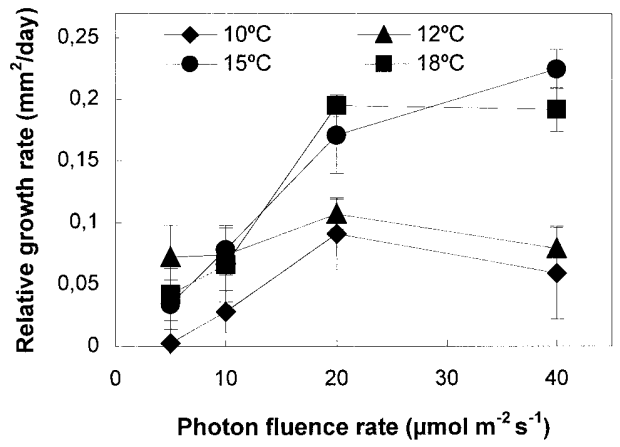

Fig. 5 Mean relative growth rate of Laminaria ochroleuca young sporophytes after 2 weeks exposure to the experimental photon fluence rate at each temperature. Bars represent standard errors

Figure 4B illustrates the variation of reproductive success with respect to culture period. Maximum values of reproductive success were obtained at 12,15 and $18^{\circ} \mathrm{C}$ with $20 \mu \mathrm{mol} \mathrm{m}-2 \mathrm{~s}^{-1}(\mathrm{RS}=1)$, and at $15^{\circ} \mathrm{C}$ with $40 \mu \mathrm{mol} \mathrm{m} \mathrm{m}^{-2} \mathrm{~s}^{-1}(\mathrm{RS}=0.98 \pm 0.01)$. Values were high at $40 \mu \mathrm{mol} \mathrm{m} \mathrm{m}^{-2} \mathrm{~s}^{-1}$ for temperatures of 12 and $18^{\circ} \mathrm{C}$ ( $\mathrm{RS}=0.74 \pm 0.06$ and $\mathrm{RS}=0.88 \pm 0.08$, respectively). Finally, as with fecundity, reproductive success at $10 \mu \mathrm{mol}$ $\mathrm{m}^{-2} \mathrm{~s}^{-1}$ was low $(\mathrm{RS}=0.15-0.35)$.

\section{Development of young sporophytes}

When young sporophytes were transferred to aerated beakers, a monostromatic blade with the basal region polystromatic and hyaline rhizoids was developed. Two weeks later, sporophytes cultivated at the highest temperatures and photon fluence rates $\left(15-18^{\circ} \mathrm{C}\right.$ and 20-40 $\mu \mathrm{mol} \mathrm{m} \mathrm{m}^{-2} \mathrm{~s}^{-1}$ ) presented a differentiated stipe and a polystromatic lamina with developed mucilage ducts. However, under all other conditions, especially at $10^{\circ} \mathrm{C}$ and at low photon fluence rates $\left(5-10 \mu \mathrm{mol} \mathrm{m}^{-2} \mathrm{~s}^{-1}\right)$, most sporophytes did not develop stipes and laminae were mainly monostromatic. Figure 5 shows the relative growth rate of young sporophytes after 2 weeks in culture. Relative growth rate seems to be light-saturated at $20 \mu \mathrm{mol} \mathrm{m} \mathrm{m}^{-2} \mathrm{~s}^{-1}$ at all experimental temperatures, although less so at $15^{\circ} \mathrm{C}$. The maximum values of this variable were attained at $15^{\circ} \mathrm{C}$ and $40 \mu \mathrm{mol} \mathrm{m} \mathrm{m}^{-2} \mathrm{~s}^{-1}$ $\left(0.23 \mathrm{~mm}^{2} / \mathrm{day}\right)$, and at $18^{\circ} \mathrm{C}$ and $20-40 \mu \mathrm{mol} \mathrm{m} \mathrm{m}^{-2} \mathrm{~s}^{-1}$ $\left(0.19 \mathrm{~mm}^{2} /\right.$ day $)$. At low temperatures $\left(10-12^{\circ} \mathrm{C}\right)$ or low photon fluence rates $\left(5-10 \mu \mathrm{mol} \mathrm{m} \mathrm{m}^{-2} \mathrm{~s}^{-1}\right)$, the relative growth rate was less than $0.1 \mathrm{~mm}^{2} /$ day.

\section{Discussion}

Our results showed that temperature is the principal factor governing germination and that this is independent of the photon fluence rates used in the experiments, although germination at $12^{\circ} \mathrm{C}$ was slightly higher at $20 \mu \mathrm{mol} \mathrm{m} \mathrm{m}^{-2} \mathrm{~s}^{-1}$. Germination independent of photon fluence rate has been observed in other species of Lami- naria (Lee and Brinkhuis 1988; Egan et al. 1989; Lee 1992). The ability to have high germination rates under all conditions may be advantageous because spores can colonize shaded and bright conditions within a kelp forest. On the other hand, studies of some Laminariales species appear to reveal apparent seasonal acclimation responses of the percentage germination (Lee and Brinkhuis 1988). The current study was not designed to show such a response but the highest germination percentages were found at the highest temperatures employed in the experiment; these were similar to the original temperature at their site of origin $\left(16-15^{\circ} \mathrm{C}\right.$ between August and October), and were lower at colder temperatures. In contrast, Lee and Brinkhuis (1988) demonstrated that percentage germination in Laminaria saccharina was not suppressed at the lowest temperature throughout the year. This difference in the temperature responses of L. ochroleuca germination may indicate that this species is not adapted to the colder water.

Optimal development of female gametophyte primary cells is important for the earliest formation of gametangia. In $L$. ochroleuca the maximum size of this primary cell is $20 \mu \mathrm{m}$ and optimal development of these cells occurs at $15-18^{\circ} \mathrm{C}$ and a photon fluence rate of 10-40 $\mu \mathrm{mol} \mathrm{m} \mathrm{m}^{-2} \mathrm{~s}^{-1}$. The optimal temperature was the same as in other European species of the genus. However, at lower temperatures $\left(10-12^{\circ} \mathrm{C}\right)$, an abrupt decrease in the diameter of the primary cell occurred in contrast to $L$. digitata, in which the diameter decreased sharply as temperatures increased (Lüning 1980). There is a clear pattern of resource allocation in gametophytes of L. ochroleuca. If fecundity is high, gametophytes stop their vegetative growth, and when reproductive success is maximum they die. However, when environmental conditions are not optimal for reproduction, gametophytes continue growing and can attain a great size. In this way, gametophytes may survive and grow in unfavourable conditions, waiting for more favourable conditions. Gametophytes of L. ochroleuca cultivated for one month at $10^{\circ} \mathrm{C}$ and $30-40 \mu \mathrm{mol} \mathrm{m}{ }^{-2} \mathrm{~s}^{-1}$ grew vegetatively and did not form gametangia, but when they were transferred to higher temperatures they became fertile (data not shown). However, gametophytes have been found only rarely in the field (Kain 1979). Lüning (1980) observed that the dominant stage of the gametophytes in experimental cultures in the sea is the unicellular stage in female gametophytes, and the few-celled stage in male gametophytes. Reed et al. (1997) observed that dormant stages of Macrocystis pyrifera and Pterygophora californica did not contribute significantly to recruitment. Therefore we expect that the optimal strategy for recruiting a large number of young sporophytes of L. ochroleuca is for gametophytes to stay at the unicellular (female) or few-celled (male) stage. This morphology is attained under optimal conditions of light and temperature (15-18 ${ }^{\circ} \mathrm{C}$ and $\left.20-40 \mu \mathrm{mol} \mathrm{m}^{-2} \mathrm{~s}^{-1}\right)$.

The mean percentage of female gametophytes ranged from $42 \%$ to $54 \%$. The results suggest nearly equal proportions of the two sexes. This is according to Evans 
(1965), who demonstrated the existence of an X/Y sexdetermining mechanism in Laminaria. However, few differences observed in L. ochroleuca are attributable to the different experimental temperatures. At $10^{\circ} \mathrm{C}$, a temperature that is unfavourable for this species, the percentage of male gametophytes was significantly higher than that of female gametophytes. Lee and Brinkhuis (1988) also found that temperature has a clear effect on the proportions of the sexes of gametophytes of $L$. saccharina 3 weeks after meiospore inoculation. These authors noted that male gametophytes were prevalent at the highest temperatures of $17^{\circ} \mathrm{C}$ and $20^{\circ} \mathrm{C}$, which are unfavourable for this species. Our results, taken with those of Lee and Brinkhuis (1988), suggest that survival of female gametophytes can be affected by temperatures that are unfavourable for development in the two species, these being higher in the case of $L$. saccharina and lower in L. ochroleuca.

Temperatures of $12-18^{\circ} \mathrm{C}$ and photon fluence rates of 20-40 $\mu \mathrm{mol} \mathrm{m} \mathrm{m}^{-2} \mathrm{~s}^{-1}$ were optimal conditions for the reproduction of $L$. ochroleuca gametophytes, yielding very high or the maximal levels of fecundity and reproductive success. Moreover, at $15-18^{\circ} \mathrm{C}$ and $20 \mu \mathrm{mol} \mathrm{m}^{-2} \mathrm{~s}^{-1}$ the maximum observed values of these reproductive variables were attained more rapidly. tom Dieck (1992) reported that gametophytes of L. ochroleuca were very susceptible to the lower temperatures and died at $5^{\circ} \mathrm{C}$ and at photon fluence rates higher than $19 \mu \mathrm{mol} \mathrm{m} \mathrm{m}^{-2} \mathrm{~s}^{-1}$. The greatest fertility she observed was at $11^{\circ} \mathrm{C}$ and $41 \mu \mathrm{mol} \mathrm{m}{ }^{-2} \mathrm{~s}^{-1}(F=0.35)$. These values are considerably lower than our results, probably because the cultures of L. ochroleuca originated from old gametophytes maintained under red light, and not from zoospores. In other species of the genus, under the same conditions of culture, greater fertility results when gametophytes were developed from zoospores (Egan et al. 1989; tom Dieck 1992). Thus the reproductive optimum of $L$. ochroleuca gametophytes occurs at temperatures and photon fluence rates greater than those of other European species of the genus, such as Laminaria digitata $\left(10^{\circ} \mathrm{C}\right.$ and $\left.10-30 \mu \mathrm{mol} \mathrm{m}-2 \mathrm{~s}^{-1}\right)$, Laminaria hyperborea $\left(10-15^{\circ} \mathrm{C}\right.$ and 5-30 $\mu \mathrm{mol} \mathrm{m}^{-2} \mathrm{~s}^{-1}$ ) and L. saccharina $\left(5-15^{\circ} \mathrm{C}\right.$ and 5-30 $\mu \mathrm{mol} \mathrm{m}{ }^{-2} \mathrm{~s}^{-1}$ ) (Lüning 1980).

The optimal conditions for the development of young L. ochroleuca sporophytes are $15-18^{\circ} \mathrm{C}$ and $20-40 \mu \mathrm{mol}$ $\mathrm{m}^{-2} \mathrm{~s}^{-1}$. tom Dieck (1992) also reported optimal growth of sporophytes of $L$. ochroleuca at temperatures of $15-20^{\circ} \mathrm{C}$, and that the young sporophytes were not able to survive at $0^{\circ} \mathrm{C}$ for 2 weeks and grew very slowly at $5^{\circ} \mathrm{C}$. She concluded that this species is the only warmtemperate species of digitate members of the genus in the northern hemisphere. Thus, optimal growth of L. ochroleuca sporophytes occurs at temperatures higher than those for other closely related species, such as L. hyperborea, L. digitata $\left(10-15^{\circ} \mathrm{C}\right.$; tom Dieck 1992), or L. saccharina $\left(10-15^{\circ} \mathrm{C}\right.$; Bolton and Lüning 1982). Laminaria abyssalis, a species from the southern hemisphere, has similar temperature requirements to $L$. ochroleuca, its optimal growth occurring at $15-20^{\circ} \mathrm{C}$
(Yoneshigue-Valentin 1990; tom Dieck and Oliveira 1993).

Young sporophytes of Laminariales are photophysiologically adapted to the dim light climate encountered in established kelp communities (Han and Kain 1996). These authors found that growth of young sporophytes of four species of European Laminariales (L. digitata, L. hyperborea, L. saccharina and Alaria esculenta) was saturated at 20-30 $\mu \mathrm{mol} \mathrm{m} \mathrm{m}^{-2} \mathrm{~s}^{-1}$ of continuous photon fluence rate. These results are similar to those obtained for L. ochroleuca, so this species may be considered to exhibit the general pattern observed in young sporophytes of Laminariales.

Along the coast of north-western Spain, L. ochroleuca and $L$. hyperborea frequently coexist in the same localities, but L. ochroleuca is found above L. hyperborea in the sublittoral zonation. Our results may explain this. We have shown that, at low photon fluence rates (less than $20 \mu \mathrm{mol} \mathrm{m} \mathrm{m}^{-2} \mathrm{~s}^{-1}$ ), L. ochroleuca gametophytes are infertile or have low fertility, and its young sporophytes have a low relative growth rate $\left(<0.1 \mathrm{~mm}^{2} /\right.$ day $)$. However, L. hyperborea is quite fertile at low photon fluence rates (Lüning 1980) and higher relative growth rates (Han and Kain 1996). In the Mediterranean Sea, L. ochroleuca is confined to greater depths due to the upper lethal temperature for the sporophyte of $22-23^{\circ} \mathrm{C}$ (van den Hoek 1982b; tom Dieck 1992), and thus has to cope with lower photon fluence rates. On the other hand, this distribution is probably also because ultraviolet radiation prevents the germination of Laminariales spores in shallow waters (Wiencke et al. 2000). For example, in the Straits of Gibraltar, L. ochroleuca lives at a depth of $30 \mathrm{~m}$ and a photon fluence rate of approximately $12 \pm 3 \mu \mathrm{mol} \mathrm{m}^{-2} \mathrm{~s}^{-1}$ in September (Flores-Moya 1997). Under these conditions, L. ochroleuca grows slowly but does not have to compete with $L$. hyperborea, and can form populations with a low density of individuals.

It is of note that gametophytes of L. ochroleuca are infertile at $10^{\circ} \mathrm{C}$, thus indicating that temperature is limiting for gametogenesis in this species. L. ochroleuca extends towards the north, to the coasts of Britain (Braud 1974) and of the south of Great Brittany (Sheppard et al. 1978; Norton 1985). The northern limit of its distribution coincides with the $10^{\circ} \mathrm{C}$ February isotherm (van den Hoek 1982a). The results obtained in this study help to explain why this species does not inhabit waters further to the north, and corroborates the findings of van den Hoek (1982a) and tom Dieck (1992). L. ochroleuca gametophytes cannot reproduce and the growth of its sporophytes is not competitive at temperatures close to $10^{\circ} \mathrm{C}$.

\section{References}

Bolton JJ, Lüning K (1982) Optimal growth and maximal survival temperatures of Atlantic Laminaria species (Phaeophyta) in culture. Mar Biol 66:89-94

Braud JP (1974) Étude de quelques paramètres écologiques, biologiques et biochimiques chez une pheophycée des côtes bretonnes, Laminaria ochroleuca. Rev Trav Inst Pêches Marit $38: 115-204$ 
Dieck I tom (1992) North Pacific and North Atlantic digitate Laminaria species (Phaeophyta): hybridization experiments and temperature responses. Phycologia 31:147-163

Dieck I tom (1993) Temperature tolerance and survival in darkness of kelp gametophytes (Laminariales, Phaeophyta): ecological and biogeographical implications. Mar Ecol Prog Ser 100:253-264

Dieck I tom, Oliveira EC (1993) The section Digitatae of the genus Laminaria (Phaeophyta) in the northern and southern Atlantic: crossing experiments and temperature responses. Mar Biol 115:151-160

Egan B, Vlasto A, Yarish C (1989) Seasonal acclimation to temperature and light in Laminaria longicruris de la Pyl. (Phaeophyta). J Exp Mar Biol Ecol 129:1-16

Evans LV (1965) Cytological studies in the Laminariales. Ann Bot 29:541-562

Flores-Moya A (1997) Changes in reproductive effort, lamina-area index, and standing crop with depth in the deep-water alga Phyllariopsis purpurascens (Laminariales, Phaeophyta). Phycologia 36:32-37

Gayral P (1957) Résultats d'une prospection algologique à l'île de Mogador. C R Acad Sci 245:358-360

Giaccone G (1969) Note sistematiche de osservazioni fitosociologiche sulle Laminariales del Mediterraneo occidentale. G Bot Ital 193:457-474

Han T, Kain JM (1996) Effect of photon irradiance and photoperiod on young sporophytes of four species of the Laminariales. Eur J Phycol 31:233-240

Hoek C van den (1982a) The distribution of benthic marine algae in relation to the temperature regulation of their life histories. Biol J Linn Soc 18:81-144

Hoek C van den (1982b) Phytogeographic distribution groups of benthic marine algae in the North Atlantic Ocean: a review of experimental evidence from life history studies. Helgol Meeresunters 35:153-214

Kain JM (1979) A view of the genus Laminaria. Oceanogr Mar Biol Annu Rev 17:101-161

Lee JA (1992) Gametogenesis and early sporophyte development of Laminaria religiosa Miyabe in the east coast of Korea. Korean J Phycol 7:109-119
Lee JA, Brinkhuis BH (1986) Reproductive phenology of Laminaria saccharina (L.) Lamour (Phaeophyta) at the southern limit of its distribution in the northwestern Atlantic Ocean. J Phycol 22:276-285

Lee JA, Brinkhuis BH (1988) Seasonal light and temperature interaction effects on development of Laminaria saccharina (Phaeophyta) gametophytes and juvenile sporophytes. J Phycol 24:181-191

Lüning K (1980) Critical levels of light and temperature regulating the gametogenesis of three Laminaria species (Phaeophyceae). J Phycol 16:1-15

Lüning K (1990) Seaweeds: their environment, biogeography and ecophysiology. Wiley Interscience, New York

Lüning K, Neushul M (1978) Light and temperature demands for growth and reproduction of laminarian gametophytes in southern and central California. Mar Biol 45:297-309

Norton TA (1985) Provisional atlas of the marine algae of Britain and Ireland. Biological Records Centre, Monks Woods Experimental Station, Huntingdon, UK

Reed DC, Anderson TW, Ebeling AW, Anghera M (1997) The role of reproductive synchrony in the colonization potential of kelp. Ecology 78:2443-2457

Sheppard CRC, Jupp BP, Sheppard ALS, Bellamy DJ (1978) Studies on the growth of Laminaria hyperborea (Gunn.) Fosl. and Laminaria ochroleuca De La Pylaie on the French Channel Coast. Bot Mar 21:109-116

Sokal RR, Rohlf FJ (1995) Biometry: the principles and practice of statistics in biological research. Freeman, New York

Starr R, Zeikus JA (1987) UTEX-The culture collection of algae at the University of Texas at Austin. J Phycol 23 [Suppl]:1-47

Tatewaki M (1966) Formation of a crustose sporophyte with unilocular sporangia in Scitosiphon lomentaria. Phycologia 6:62-66

Wiencke C, Gómez I, Pakker H, Flores-Moya A, Altamirano M, Hanelt D, Bischof K, Figueroa FL (2000) Impact of UV-radiation on viability, photosynthetic characteristics and DNA of brown algal zoospores: implications for depth zonation. Mar Ecol Prog Ser 197:217-229

Yoneshigue-Valentin Y (1990) The life cycle of Laminaria abyssalis (Laminariales, Phaeophyta) in culture. Hydrobiologia 204/205:461-466 